\title{
Laboratory assessment of the efficiency of corrosion inhibitors at oilfield pipelines of the West Siberia region V. Rotating cylinder and cage
}

\author{
I. A. Gedvillo, ${ }^{1}$ S. V. Oleinik, ${ }^{1}$ I. S. Sivokon ${ }^{2}$ and N. N. Andreev ${ }^{1}$ \\ ${ }^{1}$ A. N. Frumkin Institute of Physical Chemistry and Electrochemistry, Russian Academy \\ of Sciences, Leninskii pr. 31, Moscow, 119071 Russian Federation \\ *E-mail: n.andreev@mail.ru \\ ${ }^{2}$ Open Joint Stock Company TNK-BP Management, Moscow
}

\begin{abstract}
This paper continues a series of publications dedicated to lab assessment of efficiency of carbon dioxide corrosion inhibitors at the oilfield pipelines of West Siberia region. It reviews the results of tests performed on "rotating cylinder" and "rotating cage" facilities. The article reviews the effect of temperature, specimen surface condition, flow velocity, presence of a hydrocarbon phase and inhibitor concentration on corrosion rate and protective properties of a wide range of commercial inhibitors. Recommendations on specific inhibitor test conditions are given to assess their applicability for protection of water lines, oil pipelines with low watercut and oil pipelines with high product watercut.
\end{abstract}

Key words: corrosion inhibitors, test methods, oilfield pipelines.

Received: September 1, 2013.

doi: $10.17675 / 2305-6894-2013-2-4-287-303$

Previously [1-3], the specifics of tests in glass U-cell, flow-through recirculation loop, and bubble method have been studied to assess the efficiency of carbon dioxide corrosion inhibitors. This paper reviews the potential of another two methods for inhibitor testing that according to [4-9] are quite accurate in simulation of the corrosion scenario in oilfield pipelines, namely, the rotating cylindrical electrode and rotating cage methods.

The potential of these methods was analyzed by the example of the same inhibitors as in the previous articles [1-3], so the numeration of the inhibitors accepted there is kept unchanged. Inhibitors No. 3, 4 and 7 are qualified by the manufacturers as imidazolines and No. 5 is a quaternary ammonium base. Inhibitor No.1 is a mixture of quaternary ammonium bases and imidazoline derivatives. Inhibitors No. 2 and 6 are amines.

\section{Experimental}

The rotating cylindrical electrode method involves measuring the corrosion rates $(K)$ of a steel cylinder rotating at a certain rate in corrosive liquid media placed in an air-tight electrochemical cell. The $K$ values were estimated on the basis of specimen mass loss and by the polarization curve method [10]. At least five parallel experiments were made in each test fluid. 
The outward appearance of the unit was published previously [4]. It consists of a glass electrochemical cell fit with a jacket and an electric belt drive that ensures rotation of a metal cylinder with isolated end face surface. A platinum mesh was used as the auxiliary electrode and a saturated silver/silver chloride electrode was the reference electrode.

Before a test, the cell was washed with a detergent, with distilled water, then rinsed with ethanol and dried. After that, it was re-installed on the rack, and a cylindrical steel specimen was fastened to the shaft holder. The cell was purged down for 10 minutes with an inert gas flow to remove oxygen. To keep the required temperature $(t)$, the cell jacket was connected to the thermostat.

The simulation fluid ( 0.2 liters) prepared for the tests was pressure-forced by the inert gas flow into the test cell. After that, liquid circulation in the jacket and electrode rotation were started. The flow rate of the corrosive fluid sustained by the drive belt was $1 \mathrm{~m} / \mathrm{s}$, $1.9 \mathrm{~m} / \mathrm{s}$, or $4.1 \mathrm{~m} / \mathrm{s}$. The tests lasted for 6 hours.

In 5.0 hours after a tests start, anodic and cathodic polarization curves were recorded using an IPC-Pro potentiostat at a potentiodynamic scan rate of $60 \mathrm{mV} / \mathrm{min}$. The maximum potential displacement with respect to the corrosion potential was $0.30 \mathrm{~V}$.

The rotating "cage" method involves corrosion rate measurement of steel specimens fastened in a special cage rotated by an electric motor in liquid corrosive environments. At least three parallel experiments were made in each test fluid. The mass loss was estimated in at least six specimens from each test.

The unit layout is given in Fig. 1. It consists of a plastic cell with a heat exchanger and a hydraulic seal, and a cage with specimens rotated by an electric motor.

6

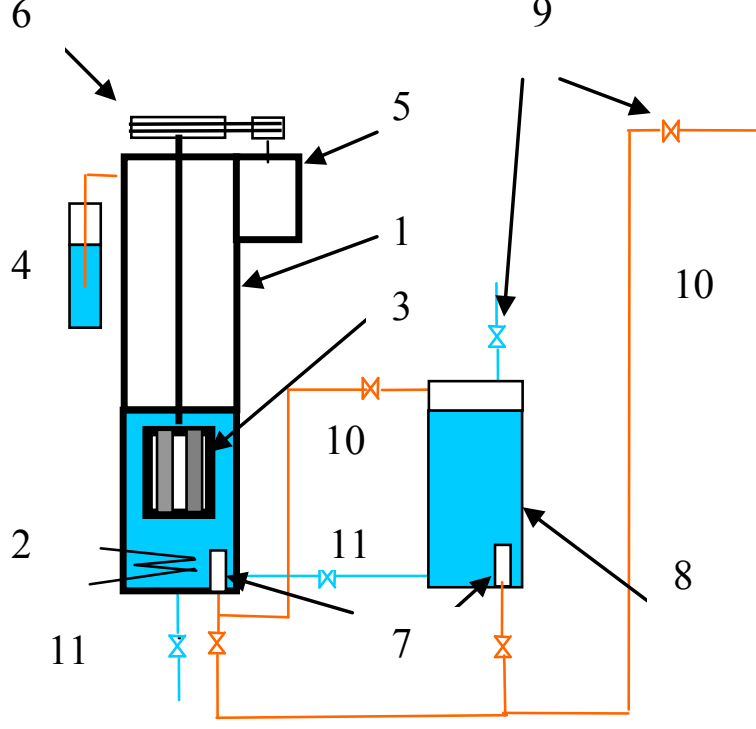

Fig. 1. Layout of the rotating cage facility. 1 , plastic cell; 2 , heat exchanger; 3 , cage with specimens; 4 , hydraulic lock; 5 , electrical motor; 6 , belt drive; 7 , bubblers; 8 , saturator vessel for model fluid preparation; 9, gas and liquid shutoff valves; 10, gas lines; 11, liquid lines. 
Before the tests, the facility was disassembled. The elements contacting a test fluid were washed with a detergent, then with distilled water and dried. After that, the cell was re-installed and the specimens mounted on the holder. The cell was purged for 30 minutes with an inert gas flow to remove dissolved oxygen.

After the simulation fluid (15 liters) was prepared for the tests, it was pressure-forced by the inert gas flow into the test cell and the electric motor was started ( $v=160 \mathrm{rpm})$ to ensure fluid circulation. The tests lasted for 6 hours. The test time was measured from the moment of cell filling with the simulation fluid.

Preparation of the specimens and the simulation fluids for the tests of both types and post-test treatment of the specimens were similar to those described in [1].

The corrosion rate $(K)$ was calculated on the basis of specimen mass loss and/or, in case of the rotating cylinder, on the basis of corrosion current data obtained through projection of the polarization curves linearized in semilog coordinates to the corrosion potential.

\section{Results and discussion}

Rotating cylinder. In all tests with the rotating cylinder, the polarization curve method provided erroneously low results. In the polarization curves built in semilog coordinates, it was impossible to outline close-to-linear sections whose projection to the corrosion potential would make it possible to estimate $K$ values comparable with those calculated on the basis of specimen mass loss. The differences between the values identified through electrochemical and gravimetric methods are illustrated in Table 1 and are very large in some cases. This made electrochemical measurements not informative and justified the gravimetrical method for this type of experiments. However, even its accuracy left much to be desired considering that the continuous operation time of the unit did not exceed 6 hours and the electrode surface was relatively small. This inherent disadvantage of the unit mostly affected the efficiency measurement accuracy for the additives tested. By the end of the test, the adsorption film of the inhibitors was still developing. Be as it may, the data obtained using this method are presented in Tables 1 and 2. The key focus of the tests was made on ranking of the additives under conditions simulating the operation of water lines and oil pipelines with low watercut.

As expected, the effect of the flow rate on $K$ in uninhibited model environments manifested itself as a $K$ growth with an increase in the electrode rotating speed (Table 1). At $1 \mathrm{~m} \cdot \mathrm{s}^{-1}$ flow rate and $t=8^{\circ} \mathrm{C}$, the $K$ values are 15.8 and $25.3 \mathrm{~g} \cdot \mathrm{m}^{-2} \cdot$ day $^{-1}$ for airoxidized and activated specimens, respectively, while at $4.1 \mathrm{~m} \cdot \mathrm{s}^{-1}$ these values increased almost twice and now equaled 30.4 and $52 \mathrm{~g} \cdot \mathrm{m}^{-2} \cdot$ day $^{-1}$, respectively. One can easily note that the $K$ value is many times smaller in electrochemical measurements. For this reason, electrochemical measurement data were not taken into consideration in subsequent analysis of results. 
Table 1. The $K$ values estimated from gravimetrical data and electrochemical measurements for various test conditions (rotating cylinder).

\begin{tabular}{|c|c|c|c|c|c|}
\hline \multirow{2}{*}{ Model fluid } & \multirow{2}{*}{$\begin{array}{c}\text { Flow rate, } \\
\mathbf{m} \cdot \mathbf{s}^{-1}\end{array}$} & \multirow{2}{*}{$t,{ }^{\circ} \mathrm{C}$} & \multirow{2}{*}{$\begin{array}{c}\text { Specimen } \\
\text { preparation }\end{array}$} & \multicolumn{2}{|c|}{$K, \mathbf{g} \cdot \mathbf{m}^{-2} \cdot$ day $^{-1}$} \\
\hline & & & & gravimetric & electrochemical \\
\hline Aqueous solution & 1 & 8 & Oxidized & 15.8 & 5.8 \\
\hline Same & 1.9 & 8 & Same & - & 3.5 \\
\hline Same & 4.1 & 8 & Same & 30.4 & 4.5 \\
\hline Same & 1 & 8 & Activated & 25.3 & 5.0 \\
\hline Same & 1.9 & 8 & Same & 40.0 & 3.9 \\
\hline Same & 4.1 & 8 & Same & 52.0 & 3.9 \\
\hline Same & 1 & 25 & Oxidized & 28.0 & - \\
\hline Same & 1 & 25 & Activated & 8.3 & - \\
\hline Two-phase fluid & 1 & 25 & Oxidized & 21 & - \\
\hline Same & 1 & 25 & Activated & 3.5 & - \\
\hline Same & 1 & 45 & Oxidized & 22 & - \\
\hline Same & 1 & 45 & Activated & 2.7 & - \\
\hline
\end{tabular}

Table 2. Inhibitor protective capacities for various test conditions (rotating cylinder).

\begin{tabular}{cccccc}
\hline Inh. no. & Model fluid & $\boldsymbol{C}_{\text {in }}, \mathbf{~ m g} / \mathbf{l}$ & $\boldsymbol{t},{ }^{\circ} \mathbf{C}$ & Specimen preparation & $\boldsymbol{Z}, \mathbf{\%}$ \\
\hline 1 & Aqueous solution & 25 & 8 & Oxidized & 89 \\
1 & Same & 25 & 8 & Activated & 87 \\
1 & Same & 25 & 25 & Oxidized & 90 \\
1 & Same & 25 & 25 & Activated & 36 \\
1 & Same & 50 & 25 & Oxidized & 79 \\
1 & Same & 50 & 25 & Activated & $<0$ \\
1 & Two-phase fluid & 25 & 8 & Oxidized & 66 \\
1 & Same & 50 & 8 & Same & 87 \\
1 & Same & 25 & 25 & Same & 82 \\
1 & Same & 25 & 25 & Activated & $<0$ \\
1 & Same & 50 & 25 & Same & 85 \\
1 & Same & 25 & 45 & Oxidized & 82 \\
1 & Same & 25 & 45 & Activated & 67 \\
1 & Same & 50 & 45 & Oxidized & 84 \\
2 & Aqueous solution & 25 & 8 & Same & 82 \\
2 & Same & 25 & 8 & Activated & 63 \\
2 & Same & 25 & 25 & Oxidized & 80
\end{tabular}




\begin{tabular}{|c|c|c|c|c|c|}
\hline Inh. no. & Model fluid & $C_{\mathrm{in}}, \mathrm{mg} / \mathrm{l}$ & $t,{ }^{\circ} \mathrm{C}$ & Specimen preparation & $Z, \%$ \\
\hline 2 & Same & 25 & 25 & Activated & 59 \\
\hline 2 & Same & 50 & 25 & Oxidized & 69 \\
\hline 2 & Same & 50 & 25 & Activated & 20 \\
\hline 2 & Two-phase fluid & 25 & 8 & Oxidized & 55 \\
\hline 2 & Same & 25 & 25 & Same & 88 \\
\hline 2 & Same & 25 & 25 & Activated & 99 \\
\hline 2 & Same & 50 & 25 & Same & 99 \\
\hline 2 & Same & 25 & 45 & Oxidized & $<0$ \\
\hline 2 & Same & 25 & 45 & Activated & 7 \\
\hline 2 & Same & 50 & 45 & Oxidized & 91 \\
\hline 2 & Same & 50 & 45 & Activated & 98.5 \\
\hline 4 & Aqueous solution & 25 & 8 & Oxidized & 98 \\
\hline 4 & Same & 25 & 25 & Same & 63 \\
\hline 4 & Same & 25 & 25 & Activated & 60 \\
\hline 4 & Same & 50 & 25 & Oxidized & 63 \\
\hline 4 & Same & 50 & 25 & Activated & 59 \\
\hline 4 & Two-phase fluid & 25 & 8 & Oxidized & 91 \\
\hline 4 & Same & 25 & 25 & Activated & 9 \\
\hline 4 & Same & 50 & 25 & Oxidized & 65 \\
\hline 4 & Same & 50 & 25 & Activated & 81 \\
\hline 4 & Same & 25 & 45 & Oxidized & 36 \\
\hline 4 & Same & 25 & 45 & Activated & 33 \\
\hline 4 & Same & 50 & 45 & Oxidized & 86 \\
\hline 5 & Aqueous solution & 25 & 8 & Same & 77 \\
\hline 5 & Same & 25 & 25 & Same & 81 \\
\hline 5 & Same & 25 & 25 & Activated & $<0$ \\
\hline 5 & Same & 50 & 25 & Oxidized & 88 \\
\hline 5 & Same & 50 & 25 & Activated & 86 \\
\hline 5 & Two-phase fluid & 25 & 8 & Oxidized & 80 \\
\hline 5 & Same & 25 & 25 & Activated & 69 \\
\hline 5 & Same & 25 & 45 & Oxidized & 44 \\
\hline 6 & Same & 25 & 45 & Activated & 26 \\
\hline 6 & Aqueous solution & 25 & 8 & Oxidized & 95.5 \\
\hline 6 & Same & 25 & 25 & Same & 81 \\
\hline 6 & Same & 25 & 25 & Activated & $<0$ \\
\hline 6 & Same & 50 & 25 & Oxidized & $<0$ \\
\hline
\end{tabular}




\begin{tabular}{cccccc}
\hline Inh. no. & Model fluid & $\boldsymbol{C}_{\text {in }}, \mathbf{~ m g} / \mathbf{l}$ & $\boldsymbol{t},{ }^{\circ} \mathbf{C}$ & Specimen preparation & $\boldsymbol{Z}, \boldsymbol{\%}$ \\
\hline 6 & Same & 50 & 25 & Activated & 60 \\
6 & Two-phase fluid & 25 & 8 & Oxidized & 57 \\
6 & Same & 25 & 25 & Activated & $<0$ \\
6 & Same & 50 & 25 & Oxidized & 93 \\
6 & Same & 50 & 25 & Activated & 57 \\
7 & Aqueous solution & 25 & 8 & Oxidized & 93 \\
7 & Same & 25 & 25 & Same & 78 \\
7 & Same & 25 & 25 & Activated & $<0$ \\
7 & Same & 50 & 25 & Oxidized & 80 \\
7 & Same & 50 & 25 & Activated & 80 \\
7 & Two-phase fluid & 25 & 8 & Oxidized & 79 \\
7 & Same & 25 & 25 & Activated & 70 \\
7 & Same & 25 & 45 & Oxidized & 36 \\
7 & Same & 25 & 45 & Activated & 67 \\
\hline
\end{tabular}

The effect of temperature on the $K$ value in the uninhibited model electrolyte is quite considerable. Thus, a temperature increase from 8 to $25^{\circ} \mathrm{C}$ caused a $K$ increase from 15.8 to $28 \mathrm{~g} \cdot \mathrm{m}^{-2} \cdot$ day $^{-1}$ according to gravimetric data (Table 1). On the other hand, in a twophase model environment at $t=25$ and $45^{\circ} \mathrm{C}$, air-oxidized specimens corroded at nearly the same rate of $21-22 \mathrm{~g} \cdot \mathrm{m}^{-2} \cdot$ day $^{-1}$ in the entire tested temperature range.

The effect of specimen activation on $K$ in the uninhibited model environments also varies. Thus, preliminary etching enhanced corrosion in the model aqueous solution at $t=$ $8^{\circ} \mathrm{C}$ : the $K$ value increased from 15.8 to $25.3 \mathrm{~g} \cdot \mathrm{m}^{-2} \cdot$ day $^{-1}$ (Table 1 ). However, at $t=25^{\circ} \mathrm{C}$ in the same electrolyte, the opposite effect of specimen activation on $K$ was observed: the $K$ value decreased from 28 to $8.3 \mathrm{~g} \cdot \mathrm{m}^{-2} \cdot \mathrm{day}^{-1}$. In the two-phase model environment at $t=$ $25^{\circ} \mathrm{C}$, activation hindered corrosion: $K$ decreased from 21.3 to $3.5 \mathrm{~g} \cdot \mathrm{m}^{-2} \cdot \mathrm{day}^{-1}$. This trend also holds at $t=45^{\circ} \mathrm{C}$.

The effect of a hydrocarbon phase on $K$ in uninhibited model environments at $1 \mathrm{~m} \cdot \mathrm{s}^{-1}$ flow rate is rather weak. According to mass loss measurements, the presence of hydrocarbons slightly slows down the corrosion of both air-oxidized and activated specimens (Table 1).

The effect of inhibitor concentration $\left(C_{\text {in }}\right)$ was expressed in most cases as a decrease in the $K$ value for steel and an increase in the protective effect $(Z)$ with a $C_{\text {in }}$ increase (Table 2). However, in the model aqueous solution, inhibitor No. 3 at $t=5$ and $25^{\circ} \mathrm{C}$ activated the corrosion of air-oxidized steel specimens in the $C_{\text {in }}$ range tested (25 and 50 $\mathrm{mg} / \mathrm{l})$. Addition of inhibitors No.5, 6 and 7 also stimulated corrosion of activated specimens at $t=25^{\circ} \mathrm{C}$ in aqueous solution at $C_{\text {in }}=25 \mathrm{mg} / \mathrm{l}$; the effect of inhibitor No. 1 at $C_{\text {in }}=50 \mathrm{mg} / 1$ was similar. 
In the model two-phase fluid, corrosion of activated specimens was stimulated upon addition of $25 \mathrm{mg} / 1$ of inhibitors No. 1,2 and 6 . At $t=45^{\circ} \mathrm{C}$, this was also observed on airoxidized specimens at $C_{\text {in }}=50 \mathrm{mg} / 1$ with inhibitor No.2.

The effect of temperature on $Z$ is different for aqueous and aqueous-organic model environments. In aqueous solution, a change in $t$ from 5 to $25^{\circ} \mathrm{C}$ caused a slight decrease in $Z$ for both air-oxidized and activated specimens. This is confirmed by the data for inhibitors No. 1-7 at $C_{\text {in }}=25 \mathrm{mg} / 1$ (Fig. 2). In the two-phase model environment, the same trend was recorded for inhibitors No. 1, 2 and 4 (Fig. 3). In case of inhibitors No. 5 and 7, conversely, the $Z$ values decreased with an increase in $t$.
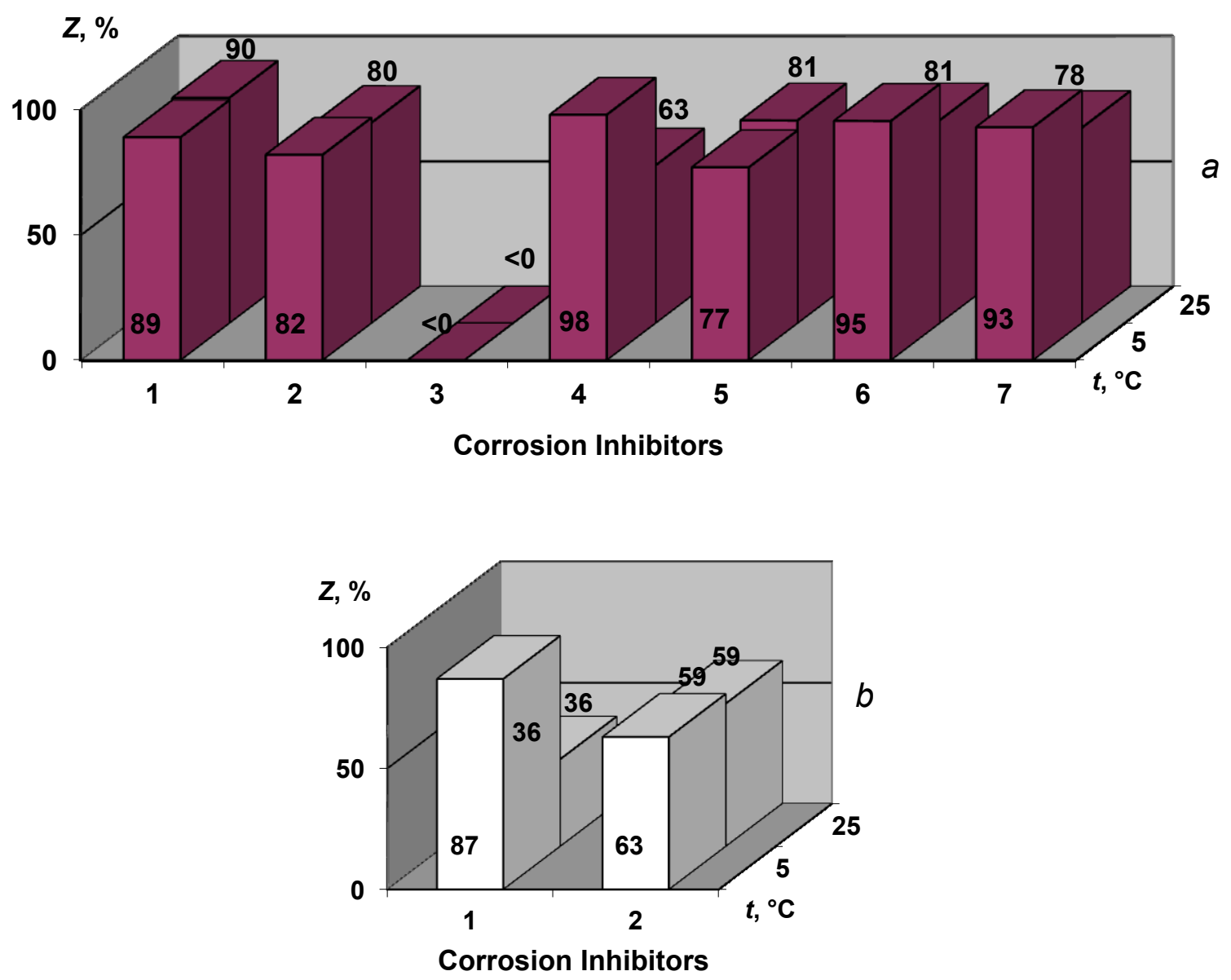

Fig. 2. Effect of temperature on the $Z$ of inhibitors $(25 \mathrm{mg} / \mathrm{l})$ for air-oxidized $(a)$ and activated (b) specimens in model aqueous solution (rotating cylinder).

The effect of specimen activation on the $Z$ of inhibitors can vary a lot (Fig. 4, 5). Subject to the inhibitor composition, concentration, $t$ and composition of the model fluid, the $Z$ values can increase or decrease. In many cases, these changes can be significant. The greatest data variation is observed in the model aqueous solution at $t=25^{\circ} \mathrm{C}$. Inhibitors No. 5,6 and 7 that slightly stimulated corrosion of activated specimens demonstrate protective effects of about $80 \%$ on air-oxidized steel. The decrease in $Z$ upon activation of specimens 
is less evident for inhibitors No. 1, 2 and 4. Inhibitor No. 3 stimulates corrosion under the test conditions on specimens of both types.

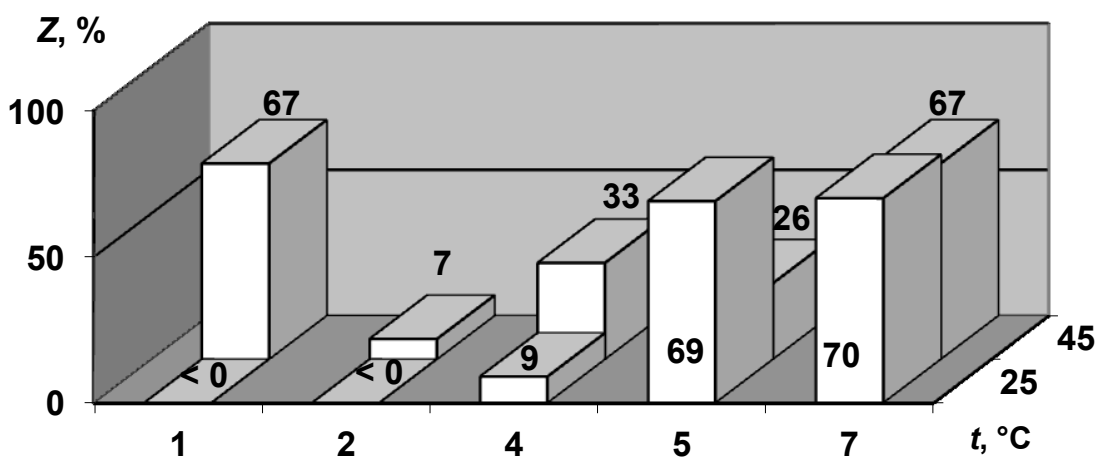

Corrosion Inhibitors

Fig. 3. Effect of temperature on the $Z$ of inhibitors $(25 \mathrm{mg} / \mathrm{l})$ for activated specimens in twophase model fluid (rotating cylinder).

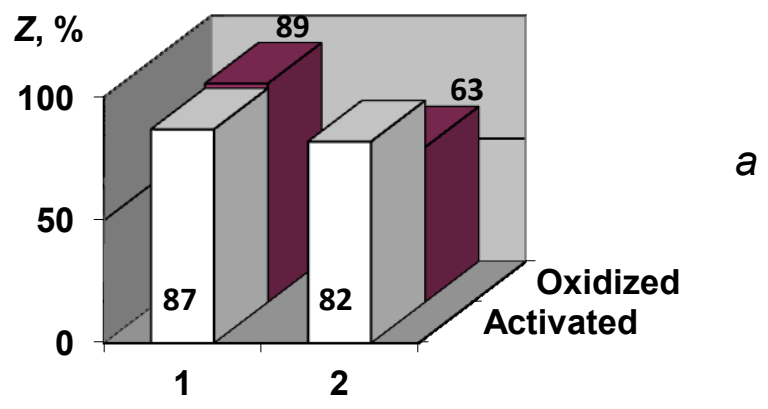

\section{Corrosion Inhibitors}

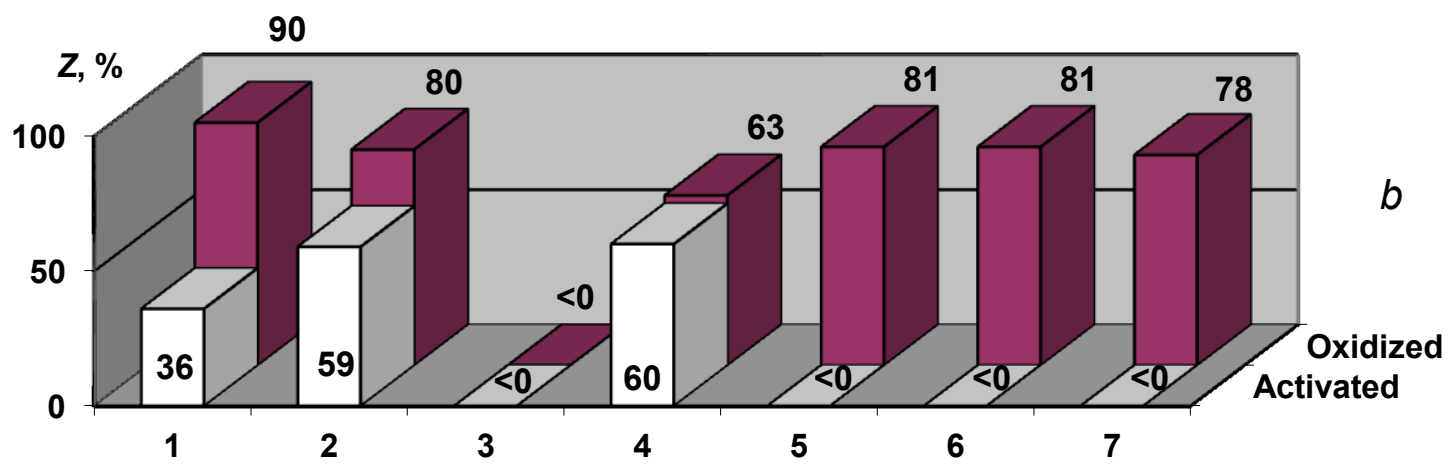

Corrosion Inhibitors

Fig. 4. Effect of steel activation on the $Z$ of inhibitors $(25 \mathrm{mg} / 1)$ in model aqueous solution at $5^{\circ} \mathrm{C}(a)$ and $25^{\circ} \mathrm{C}(b)$ (rotating cylinder). 


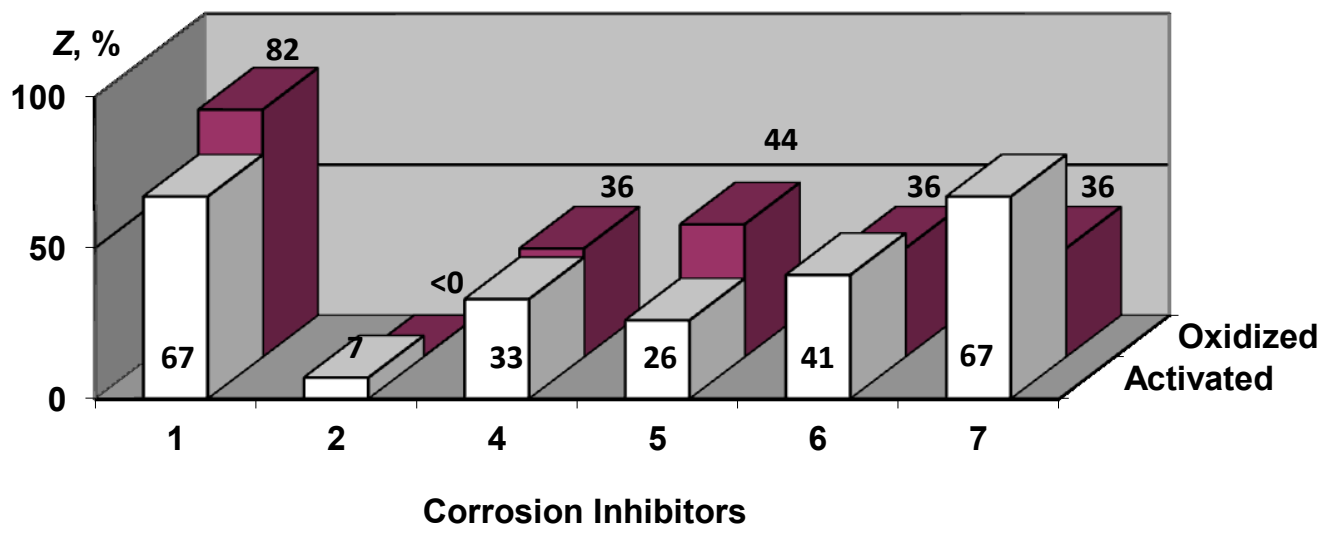

Fig. 5. Effect of steel activation on the $Z$ of inhibitors $(25 \mathrm{mg} / \mathrm{l})$ in two-phase model fluid at $25^{\circ} \mathrm{C}$ (rotating cylinder).

In the model two-phase environment, the decrease in the protective properties upon specimen activation is demonstrated by inhibitors 1,4 and 5 , whereas the protective properties of inhibitors No. 2, 6 and 7 increase.

The effect of the hydrocarbon phase on the $Z$ value differed for different inhibitors (Fig. 6). The major part of statistics was acquired on activated specimens at $C_{\text {in }}=25 \mathrm{mg} / 1$ and $t=25^{\circ} \mathrm{C}$. Addition of hydrocarbons can either notably facilitate (inhibitors No. 5 and 7) or hinder (inhibitors No. 1, 2 and 4) steel protection.

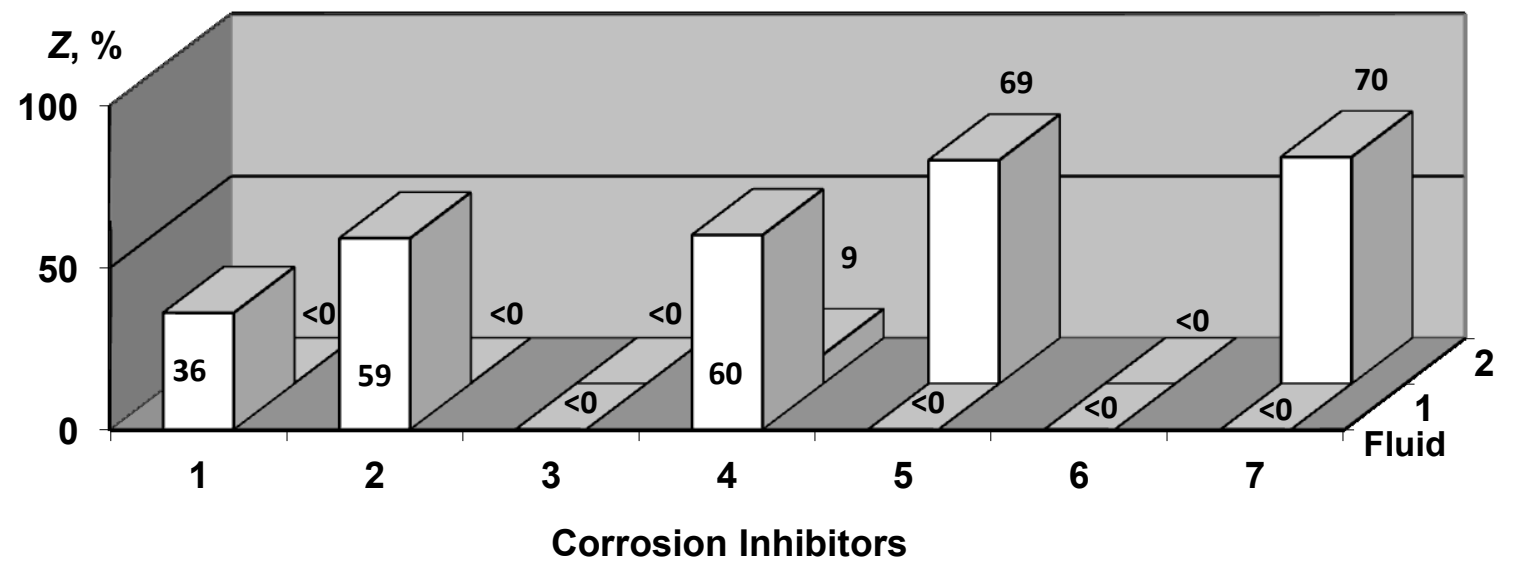

Fig. 6. The $Z$ value of inhibitors $(50 \mathrm{mg} / \mathrm{l})$ in model aqueous solution (fluid 1) and two-phase fluid (fluid 2) at $25^{\circ} \mathrm{C}$ for activated specimens (rotating cylinder).

The ranking of inhibitors was based on the most reliable gravimetrical method and air-oxidized specimens as the test results were more reproducible in this case (Fig. 7). At $t=8^{\circ} \mathrm{C}$, the best inhibitors in terms of protective properties on air-oxidized specimens $\left(C_{\text {in }}=\right.$ $25 \mathrm{mg} / \mathrm{l}$ ) form up the series:

$$
\text { No. } 4(98 \%)>\text { No. } 6(95.5 \%)>\text { No. } 7(93 \%)=\text { No. } 1(93 \%) \text {. }
$$



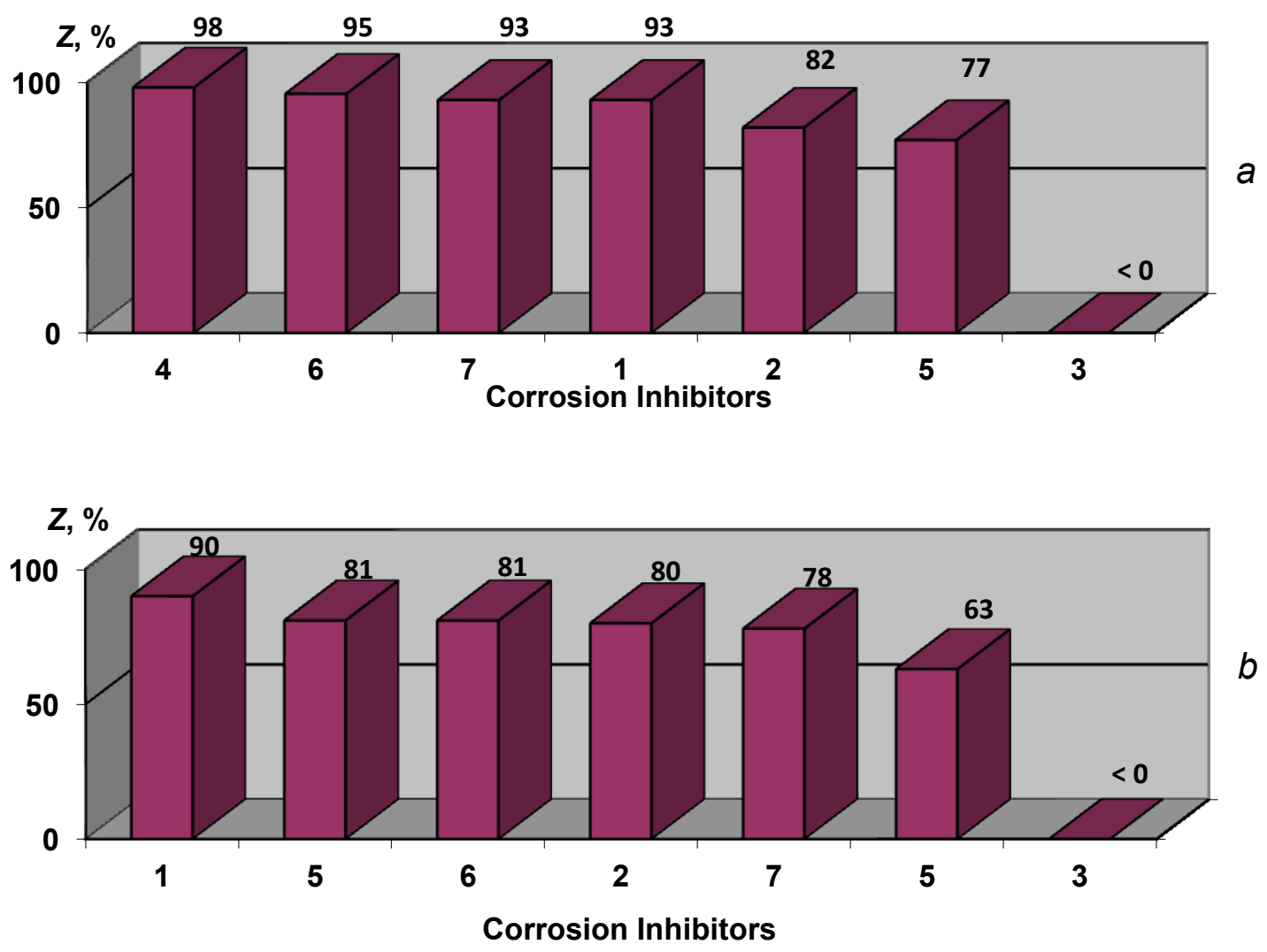

Fig. 7. The $Z$ values of chemicals $\left(a, 8^{\circ} \mathrm{C} ; b, 25^{\circ} \mathrm{C}\right)$ in model aqueous solution at $25 \mathrm{mg} / 1$ for air-oxidized specimens (rotating cylinder).

The "top list" at $t=25^{\circ} \mathrm{C}$ looks as follows:

No. $1(90 \%)>$ No. $5(81 \%)=$ No. $6(81 \%)>$ No. $2(80 \%)$.

It is essential that under the same conditions but at $C_{\text {in }}=50 \mathrm{mg} / 1$, inhibitor No. 6 activates steel corrosion. In view of this, it was excluded from the analysis. Inhibitor No. 1 is common to both "top lists". Chemical No. 3 was the worst under all the conditions studied.

The more reliable gravimetric method was used in ranking of the inhibitors in tests simulating the operation of oil pipelines with low watercut (the two-phase model fluid). The data obtained at $t=5-25^{\circ} \mathrm{C}$ do not make it possible to rank the chemicals. For this reason, assessment of inhibitor applicability for protection of oil pipelines with low watercut was based on the $Z$ values measured on air-oxidized and activated specimens at $t=45^{\circ} \mathrm{C}$ (Fig. 8). The inhibitor dose was $25 \mathrm{mg} / \mathrm{l}$. Under these conditions, the list of the best inhibitors in terms of protective properties for air-oxidized specimens is as follows:

$$
\text { No. } 1(82 \%)>\text { No. } 5(44 \%)>\text { No. } 4,6 \text { and } 7(36 \%) \text {; }
$$

for activated specimens:

$$
\text { No. } 1(67 \%)=\text { No. } 7(67 \%)>\text { No. } 6(41 \%)
$$

Inhibitor No. 1 is common to both "top lists". 

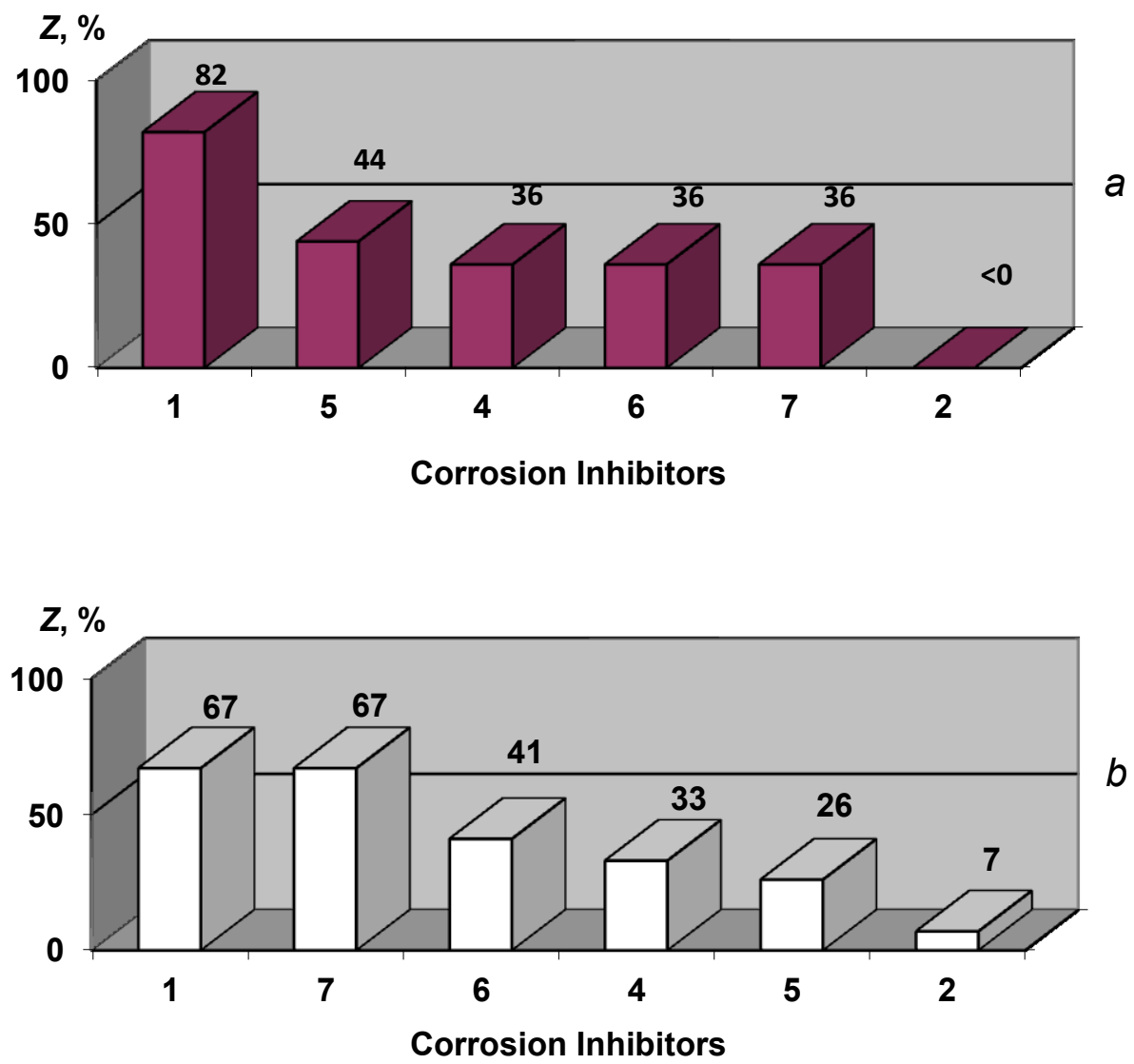

Fig. 8. The $Z$ values of inhibitors $(25 \mathrm{mg} / \mathrm{l})$ in two-phase model fluid at $45^{\circ} \mathrm{C}$ for air-oxidized $(a)$ and activated $(b)$ specimens (rotating cylinder).

Rotating Cage. The effect of $T$ on the $K$ value in all other tests of this type consisted of corrosion intensification upon system heating (Table 3). In the tests simulating the operational conditions of oil pipelines transporting products with high watercut (the twophase model fluid), an increase in $t$ from 25 to $45^{\circ} \mathrm{C}$ leads to a $K$ increase from 7 to 29.6 and 6.6 to $29.0 \mathrm{~g} \cdot \mathrm{m}^{-2} \cdot \mathrm{day}^{-1}$ for air-oxidized and acid-activated specimens, respectively.

Table 3. The $K$ values estimated for various test conditions (rotating cage).

\begin{tabular}{cccc}
\hline Model fluid & $\boldsymbol{t},{ }^{\circ} \mathbf{C}$ & Specimen preparation & $\boldsymbol{K}, \mathbf{g} \cdot \mathbf{m}^{\mathbf{- 2}} \cdot \mathbf{d a y}^{\mathbf{- 1}}$ \\
\hline Two-phase fluid & 25 & Oxidized & 6.6 \\
Same & 45 & Same & 29.5 \\
Same & 25 & Activated & 7.0 \\
Same & 45 & Same & 29.0 \\
Aqueous solution & 25 & Oxidized & 11.9 \\
Same & 25 & Activated & 9.6 \\
\hline
\end{tabular}


Specimen activation by acid etching nearly does not affect values $K$ across the range of conditions analyzed (Table 3 ). Differences in the $K$ values for air-oxidized and activated specimens did not exceed the test error.

Addition of hydrocarbons to the model fluid slows down the corrosion (Table 3). Thus, for air-oxidized specimens in the model aqueous solution at $t=25^{\circ} \mathrm{C}, K=11.9 \mathrm{~g} \cdot \mathrm{m}^{-2} \cdot$ day $^{-1}$, while in the model two-phase fluid containing $5 \%$ white spirit, $K=7.0 \mathrm{~g} \cdot \mathrm{m}^{-2} \cdot$ day $^{-1}$. In case of specimens activated by acid etching, the $K$ value decreased from 9.6 to $6.6 \mathrm{~g} \cdot \mathrm{m}^{-2} \cdot$ day $^{-1}$ after addition of the same quantity of hydrocarbons.

The tested inhibitors reduce steel $K$ in most cases at $25 \mathrm{mg} / \mathrm{l}$, although exceptions from this rule were observed (Fig. 9). In fact, addition of inhibitor No.1 to the two-phase model fluid stimulated corrosion of the activated specimens at $t=25^{\circ} \mathrm{C}$.

The effect of temperature on the $Z$ value was studied for the two-phase model fluid. In all cases, an increase in $t$ from 25 to $45^{\circ} \mathrm{C}$ improved steel protection (Fig. 10).

The effect of specimen activation on the $Z$ value of inhibitors manifested itself as a decrease in the protective effect. This effect was observed in all tests completed on the rotating cage facility (Fig. 9).

The effect of hydrocarbon phase on the $Z$ value of inhibitors varies (Fig. 11). Comparison of $Z$ values obtained for the inhibitors tested in the model aqueous solution and in the two-phase fluid demonstrates that the $Z$ values could increase, decrease, or stay the same subject to the chemical selected and specimen preparation.

In fact, for air-oxidized specimens, an increase in $Z$ after hydrocarbon addition is observed for inhibitors No.2, 6 and 7. Conversely, the efficiency of inhibitors No.1, 3, 4, and 5 decreases.

For activated specimens, white spirit addition to the system is accompanied by an increase in $Z$ if inhibitors No. 2 and 6 are used. The opposite effect is typical of inhibitors No. 1, 3 and 7. In case of inhibitors No.4 and 5, transition from the model aqueous electrolyte to the two-phase fluid practically does not affect the protection efficiency.

To rank inhibitors in the simulation of oil pipelines transporting products with high watercut (two-phase model fluid), the key focus was made on $t=45^{\circ} \mathrm{C}$. This is because under these conditions, even the best tested inhibitors provided a decrease $K$ to a level close to the corrosion rate in uninhibited electrolyte at $t=25^{\circ} \mathrm{C}$. Thus, the protective capacity of inhibitors at low $t$ is not likely to have a strong effect on the protection status of this type of pipelines where the failure rate is defined by the operation modes and the sections with increased temperature.

Under the conditions studied, the inhibitor "top list" at $25 \mathrm{mg} / 1$ concentration with airoxidized specimens was as follows (Fig. 12):

$$
\text { No. } 1(98.9 \%)>\text { No. } 4(97.2 \%)>\text { No. } 6(96.8 \%) \text {. }
$$

It is practically the same as the "top list" for activated specimens:

$$
\text { No. } 1(95.3 \%)>\text { No. } 4(92.6 \%)>\text { No. } 6(92.5 \%) \text {. }
$$

In both cases, the worst performance was provided by inhibitors No. 7 and No. 2 . 

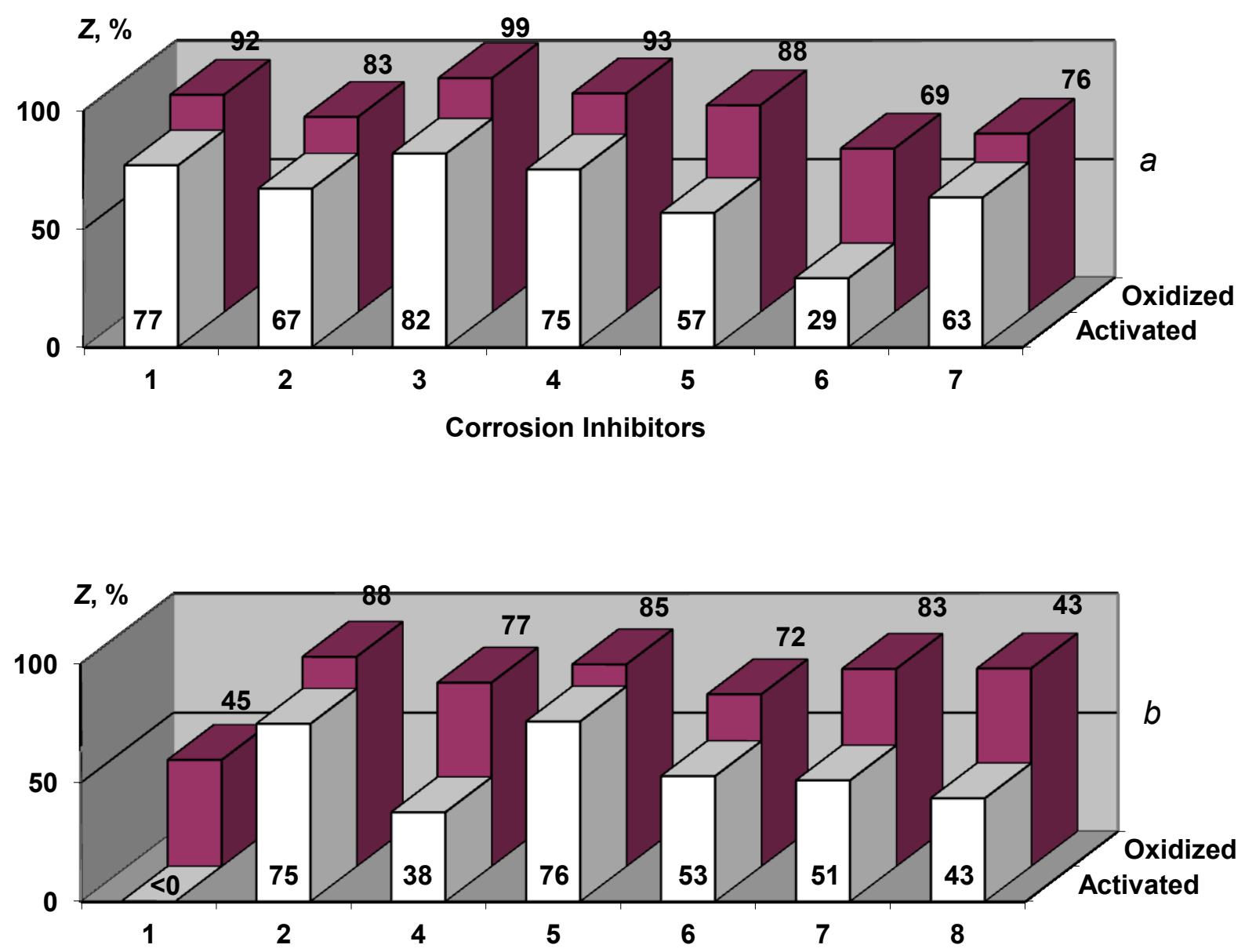

Corrosion Inhibitors

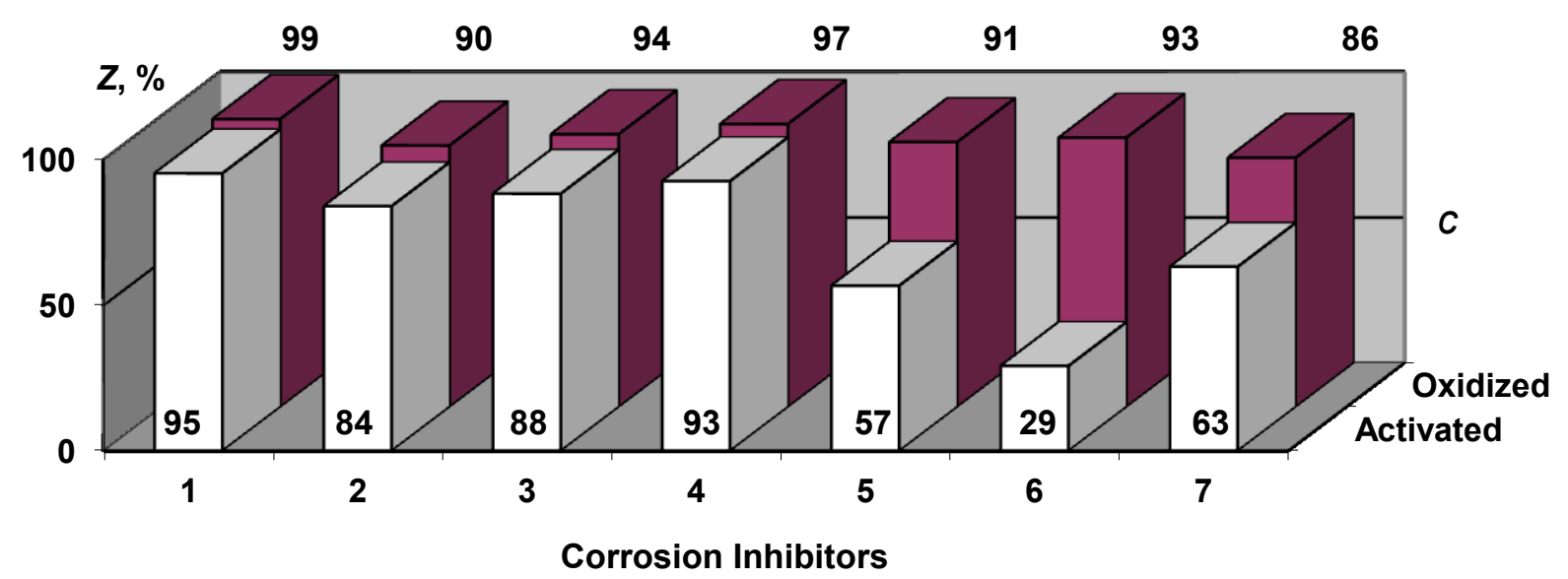

Fig. 9. Effect of inhibitors on the $Z$ value for air-oxidized and activated specimens in model aqueous solution at $25^{\circ} \mathrm{C}(a)$, in two-phase model fluid at $25(b)$ and $45^{\circ} \mathrm{C}(c)$ (rotating cage). 

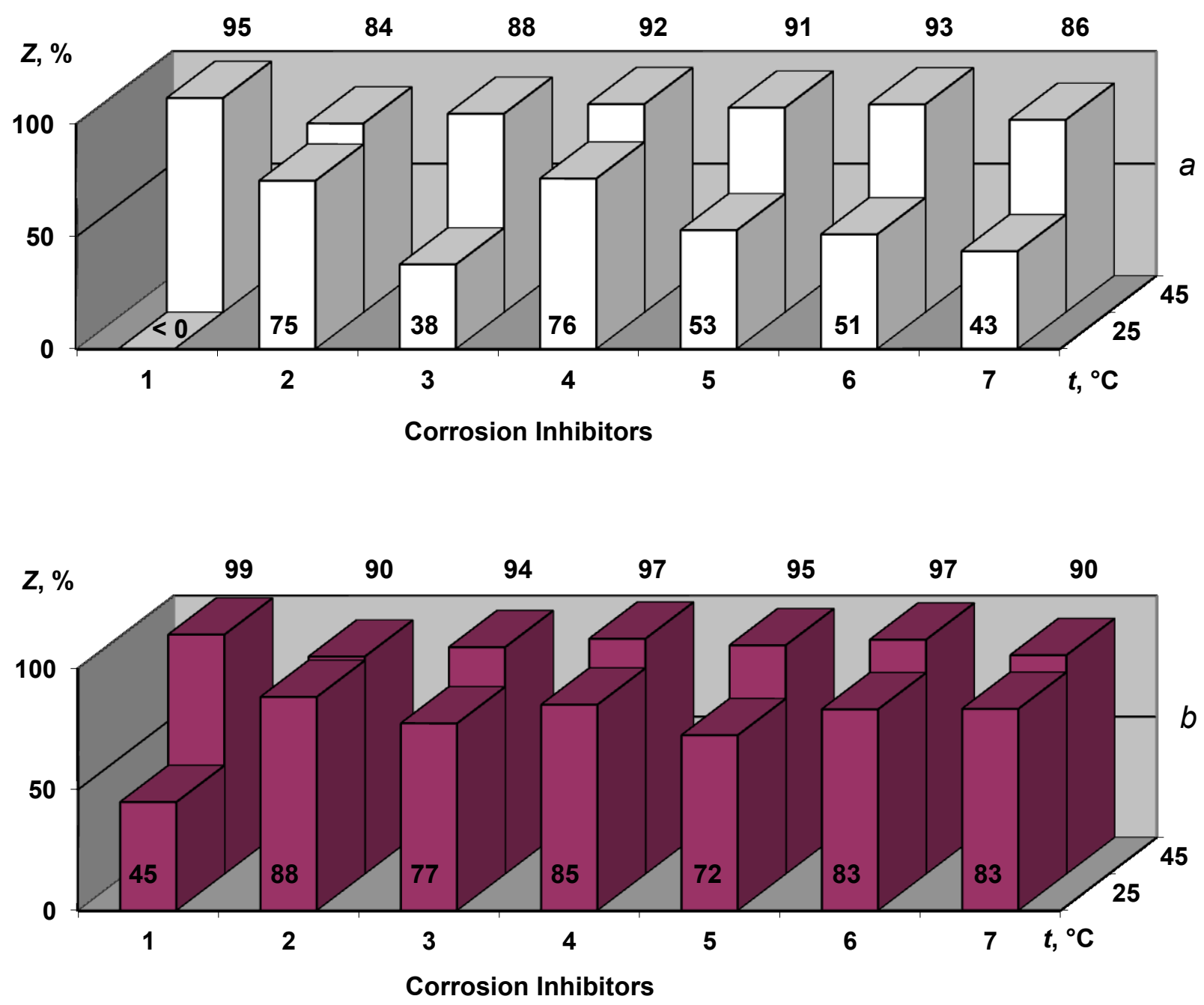

Fig. 10. Effect of temperature on the $Z$ of inhibitors for air-oxidized $(a)$ and activated $(b)$ specimens in two-phase model fluid $\left(C_{\text {in }}=25 \mathrm{mg} / \mathrm{l}\right)$ (rotating cage).

However, addition of inhibitor No. 1 to the two-phase model fluid $(25 \mathrm{mg} / \mathrm{l}$ at $t=$ $25^{\circ} \mathrm{C}$ ) stimulates the corrosion of activated specimens, which prevents us from including it in the list of compounds recommended for protection of oil pipelines with high watercut.

\section{Conclusions}

1. The rotating cylinder test cannot be used in combination with the polarization curves method under the conditions simulated (fluids and temperature range). In all tests of this type, the polarization curve method provides erroneously low results.

2. The accuracy of the rotating cylinder method in combination with the mass loss method for the corrosion kinetics measurements is low if this type of equipment is used. This effect was particularly pronounced in efficiency measurements of the inhibitors tested when the adsorption film did not have enough time to develop during the test. 

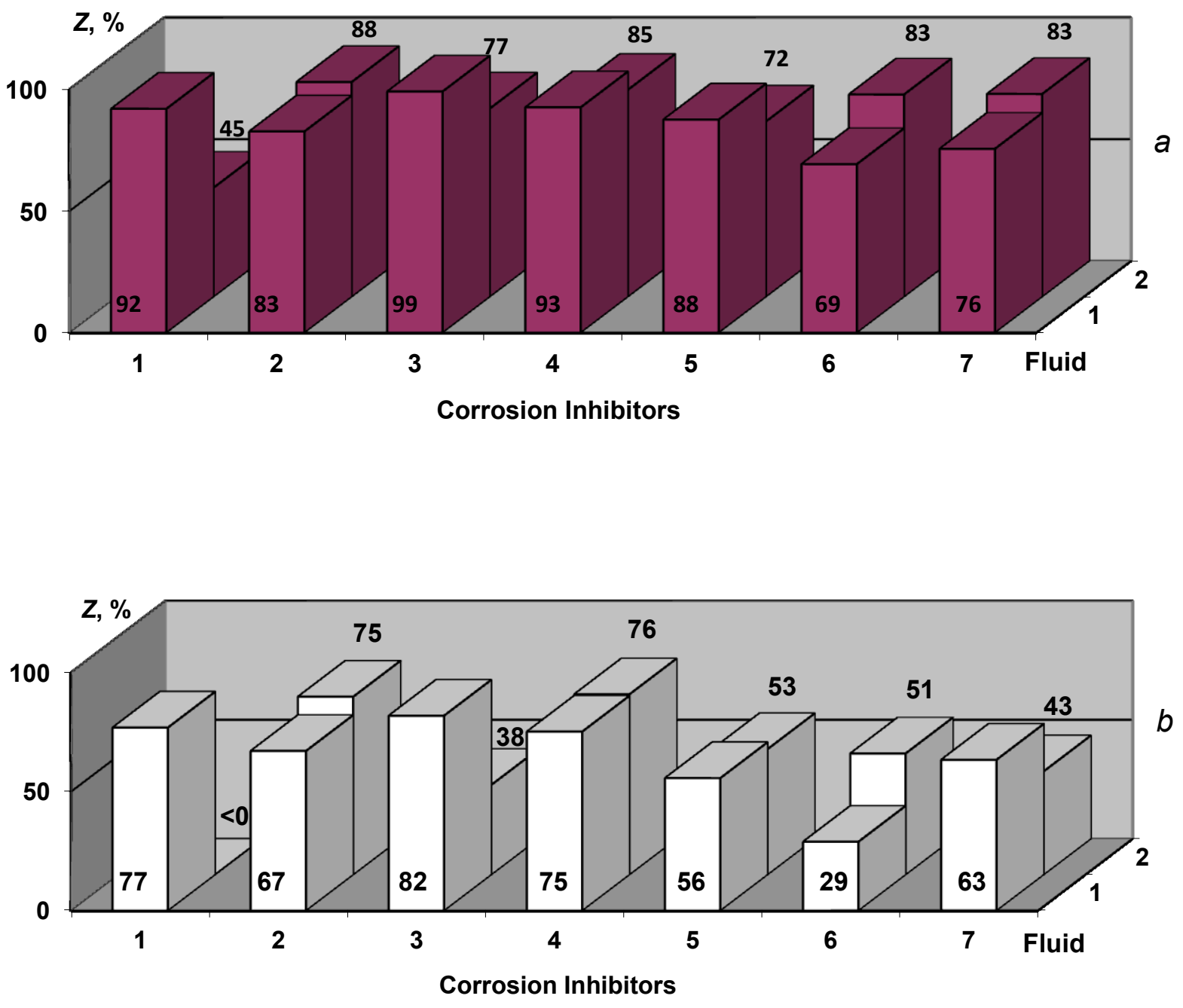

Fig. 11. Effect of hydrocarbon phase on the $Z$ value for air-oxidized (a) and activated (b) specimens at $25^{\circ} \mathrm{C}\left(C_{\text {in }}=25 \mathrm{mg} / \mathrm{l}\right)$ (rotating cage).

3. The rotating cylinder method allows us to recommend inhibitor No.1 for the protection of water lines and oil pipelines with low watercut.

4. In estimation of the inhibitor protective properties by the rotating cage method, the key focus should be made on the highest temperature mode in oil pipelines with wet products. The protective capacity of inhibitors at low temperatures does not have a strong effect on the protection of pipelines with wet products where the failure rate is defined by the operation modes and the sections with elevated temperatures.

5. Tests on the rotation cage facility allow us to recommend inhibitors No. 4 and 6 to protect oil pipelines that carry wet products. 

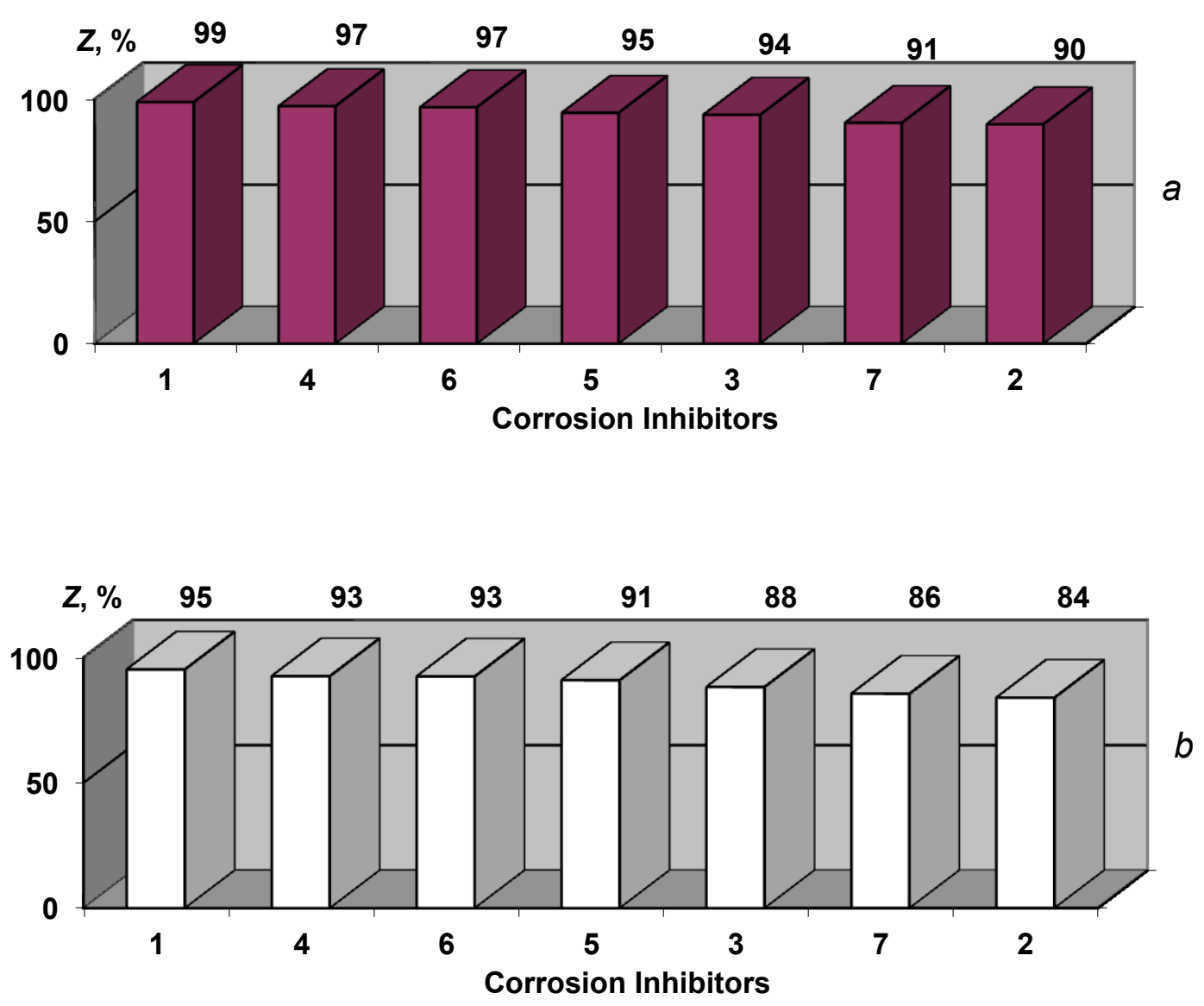

Fig. 12. The $Z$ value of inhibitors $(25 \mathrm{mg} / \mathrm{l})$ in two-phase model fluid at $25^{\circ} \mathrm{C}$ (rotating cage).

6. According to data obtained on the rotating cage facility, the "top lists" for air-oxidized and activated specimens are actually the same. This justifies a less sophisticated treatment of specimens that does not require acid etching.

\section{References}

1. I. S. Sivokon, D. B. Vershok and N.N. Andreev, Int. J. Corros. Scale Inhib., 2012, 1, no. 2, 130. doi: $10.17675 / 2305-6894-2012-1-2-130-145$

2. N. N. Andreev, N. G. Anufriev and I. S. Sivokon, Int. J. Corros. Scale Inhib., 2013, 2, no. 1, 17. doi: $10.17675 / 2305-6894-2013-2-1-017-029$

3. I. S. Sivokon, Y. B. Makarychev, Y. A. Kuzenkov and N. N. Andreev, Int. J. Corros. Scale Inhib., 2013, 2, no. 3, 203. doi: 10.17675/2305-6894-2013-2-3-203-215

4. I. S. Sivokon and N. N. Andreev, Int. J. Corros. Scale Inhib., 2012, 1, no. 1, 65. doi: 10.17675/2305-6894-2012-1-1-065-079

5. D. S. Silverman, CORROSION/90, Houston, NACE, Paper No. 13. 
6. S. Papavinasam, R. V. Revie and M. Bartos, CORROSION/2004, Houston, NACE, Paper No. 42.

7. S. Papavinasam, R. V. Revie, M. Attard, A. Demoz, H. Sun, J. C. Donini and K. Michaelian, 9th Europ. Symp. on Corrosion Inhibitors, Ferrara, 2000, 989.

8. S. Papavinasam, R. V. Revie, M. Attard, A. Demoz, J. C. Donini and K. Michaelian, CORROSION/2001, Houston, NACE, Paper No. 01061.

9. ASTM standard G 170-06. Standard guide for evaluating and qualifying oilfield and refinery corrosion inhibitors in the laboratory, ASTM International, 2006.

10. GOST 9.506-87, Unified system of protection from corrosion and ageing. Metal corrosion inhibitors in water and crude environment. Protective capacity testing methods, Moscow, Standards publishing house, 1988 (in Russian). 